\title{
Hubungan Motivasi Belajar, Bimbingan Akademik dengan Prestasi Akademik Mahasiswa Jurusan Pendidikan Bahasa dan Sastra Indonesia, Fakultas Bahasa dan Seni, Universitas Negeri Manado
}

\author{
Oldie Stevie Meruntu \\ Jurusan Pendidikan Bahasa dan Sastra Indonesia, Fakultas Bahasa dan Seni Universitas Negeri \\ Manado \\ oldiemeruntu@unima.ac.id
}

\begin{abstract}
Abstrak. Penelitian ini bertujuan: (1) mengetahui hubungan motivasi belajar dengan prestasi akademik mahasiswa Jurusan Pendidikan Bahasa dan Sastra Indonesia, Fakultas Bahasa dan Seni Universitas Negeri Manado dan (2) mengetahui hubungan antara bimbingan akademik dengan prestasi akademik mahasiswa Jurusan Pendidikan Bahasa dan Sastra Indonesia, Fakultas Bahasa dan Seni Universitas Negeri Manado. Metode yang digunakan dalam penelitian ini adalah metode kuantitatif dengan jenis rancangan korelasional. Populasi penelitian ini adalah mahasiswa semester III, V, dan VII yang berjumlah 420 orang, sedangkan sampel penelitian berjumlah 41 mahasiswa, yang diambil secara acak dari setiap semester tersebut. Hasil penelitian yang telah dilakukan, menunjukkan: (1) terdapat hubungan yang positif antara motivasi belajar dengan prestasi akademik mahasiswa Jurusan Pendidikan Bahasa dan Sastra Indonesa, Fakultas Bahasa dan Seni, Universitas Negeri Manado. Hasil penelitian menunjukkan bahwa angka korelasi yang diperoleh dari kedua variabel ini sebesar 2,063. Dari hasil pengujian tampak bahwa $\mathrm{r}$ hitung 2,063 lebih besar dari $\mathrm{r}$ tabel 0,308. Dengan demikian, korelasinya signifikan. (2) Terdapat hubungan yang positif antara bimbingan akademik dengan prestasi akademik mahasiswa Jurusan Pendidikan Bahasa dan Sastra Indonesia, Fakultas Bahasa dan Seni, Universitas Negeri Mamando. Hasil menunjukkan hubungan yang sangat positif antara motivasi belajar dengan prestasi akademik menunjukkan angka 2,27. Jika dihubungkan dengan $r$ tabel sebesar 0,308, sedangkan $r$ hitung adalah 2,27. Tampak bahwa $r$ hitung lebih besar dari $r$ tabel, sehingga hubungannya signifikan.
\end{abstract}

Kata Kunci: Hubungan, Motivasi Belajar, Bimbingan Akademik, Prestasi Akademik

\section{PENDAHULUAN}

Tolok ukur mutu pendidikan tinggi indikator utamanya adalah kualitas para lulusan. Oleh sebab itu, menjadi syarat mutlak pencapaian hasil belajar yang baik bagi mahasiswa. Disadari hasil belajar atau prestasi akademik mahasiswa di perguruan tinggi dipengaruhi oleh berbagai faktor. (Tu'u, 2004) menyatakan hasil belajar mahasiswa dipengaruhi faktor-faktor antara lain: kecerdasan, bakat, minat, dan perhatian, motivasi, cara belajar, lingkungan keluarga dan sekolah. Adapun faktor yang menghambat prestasi akademik mahasiswa antara lain: kurangnya disiplin diri dan disiplin dalam belajar baik di rumah maupun disekolah, seperti kurangnya kesadaran diri untuk belajar sendiri, kurang giat belajar, kurang banyak waktu untuk belajar di rumah.

Faktor lain yang mempengaruhi prestasi akademik mahasiswa adalah motivasi. Hamalik dalam (Djamarah, 2002) motivasi adalah suatu perubahan energi di dalam pribadi seorang yang ditandai dengan timbulnya efektif (perasaan) dan reaksi untuk mencapai tujuan. Demikian juga, dalam proses belajar, seseorang yang tidak mempunyai motivasi belajar, tidak akan mungkin melakukan aktivitas belajar dan prestasi akademiknya pun akan rendah. Sebaliknya, seseorang yang mempunyai motivasi belajar tinggi, akan dengan baik melakukan aktivitas belajar dan memiliki prestasi akademik yang lebih baik. Adapun fungsi motivasi ada tiga Sadirman (Majid, 2013) yaitu (1) mendorong manusia untuk berbuat, jadi sebagai penggerak atau motor yang melepaskan energi, (2) menentukan arah perbuatan yakni ke arah tujuan yang hendak dicapai, dan (3) seorang mahasiswa yang akan menghadapi 
ujian dengan harapan dapat lulus, tentu akan melakukan kegiatan belajar dan tidak akan menghabiskan waktunya untuk bermain atau membaca komik, sebab tidak serasi dengan tujuan.

Faktor lain yang turut menunjang prestasi akademik mahasiswa adalah bimbingan akademik yang dilaksanakan di perguruan tinggi. Kartadinata (2004) mengartikan bimbingan akademik sebagai proses membantu individu untuk mencapai perkembangan optimal. Bimbingan diorientasikan pada pemberian bantuan kepada individu agar mampu memahami diri dengan lingkungannya dan menemukan solusisolusi terhadap permasalahan yang dihadapi.

Universitas Negeri Manado merupakan salah satu lembaga pendidikan tinggi ternama di Sulawesi Utara. Sesuai visi dan misinya, Universitas Negeri Manado berusaha menghasilkan lulusan yang bermutu, berbudi pekerti luhur sehingga mampu memberikan kontribusi yang konstruktif bagi kemajuan bangsa dan negara. Salah satu program studi yang menyelenggarakan proses pembelajaran di Universitas Negeri Manado adalah Pendidikan Bahasa, Sastra Indonesia, dan Daerah, yang menyelenggarakan program pendidikan strata satu (S1). Beban studi program S1 sekurang-kurangnya 154 SKS dan sebanyak-banyaknya 160 SKS yang dijadwalkan 8 Semester (Panduan Akademik Universitas Negeri Manado, 2017). Program studi pendidikan bahasa, sastra Indonesia dan Daerah memilik jurusan, yakni Pendidikan Bahasa dan Sastra Indonesia.

Mahasiswa Jurusan pendidikan Bahasa Indonesia memiliki keragaman dari segi kemampuan akademik. Kemampuan akademik mahasiswa dapat dikelompokkan menjadi tiga, yakni kurang, sedang, dan tinggi. Para mahasiswa ini dibaurkan ke dalam kelas secara paralel berdasarkan tahun masuk. Oleh karena kemampuan akademik yang beragam, maka prestasi kademik pun beragam. Karena ini, untuk mengatasi kesenjangan akademik di antara mahasiswa ini maka masing-masing mahasiswa memiliki dosen penasihat akademik (PA). sebagai salah satu layanan akademik bagi mahasiswa. Setiap mahasiswa mendapat dosen Penasehat Akademik (PA). Dosen PA memberikan bimbingan akademik kepada mahasiswa baik secara individu maupun kelompok menghadapi kesulitan belajar mengikuti kegiatan perkuliahan. Setiap saat, mahasiswa dapat berkonsultasi dengan dosen PA tentang kesulitan belajar yang mereka alami. Hasilnya mahasiswa mendapatkan solusi mengatasi kesulitan belajar yang mereka alami, seperti kedisiplinan menigikuti perkuliahan dan prestasi belajar meningkat.

Hasil observasi awal yang dilakukan oleh peneliti sebagai dosen memperoleh data bahwa terdapat mahasiswa yang motivasi belajar masih kurang. Hal ini dibuktikan dengan ketika proses belajar mengajar ada mahasiswa yang kurang responsif dan bersikap masa bodoh ketika diberikan tugas. Mereka selalu memberikan alasan sudah terlalu banyak tugas yang diberikan. Saat diminta untuk belajar mandiri hanya beberapa mahasiswa yang melakukannya. Dampaknya, mereka mendapat nilai ujian yang kurang memuaskan. Bahkan, tidak lulus pada mata kuliah tertentu. Selain itu juga pelaksanaan bimbingan oleh dosen PA belum dilakukan secara maksimal. Hal ini mungkin disebabkan oleh belum intensnya pelaksanaan bimbingan dosen PA. Padahal motivasi belajar dan bimbingan akademik merupakan dua faktor yang berpengaruh secara langsung pada prestasi belajar atau akademik mahasiswa.

Permasalahan yang teridentifikasi adalah (1) kurangnya tenaga pengajar yang tidak lagi sebanding dengan rasio jumlah mahasiswa; (2) faktor kecerdasan mahasiswa sehingga berpengaruh juga pada prestasi akademik yang sangat beragam pula; (3) motivasi belajar mahasiswa masih kurang dan bersikap masa bodoh terhadap tugas dosen; dan (4) kurang maksimalnya bimbingan akademik oleh dosen PA untuk mengatasi kesulitan belajar yang dialami mahasiswa. Penelitian ini bertujuan utuk mengetahui seberapa besar hubungan motivasi belajar dengan prestasi akademik mahasiswa Jurusan Pendidikan Bahasa dan Sastra Indonesia, Fakultas Bahasa dan Seni, Universitas Negeri Manado dan mengetahui seberapa besar hubungan bimbingan akademik dengan prestasi akademik mahasiswa Jurusan Pendidikan Bahasa dan Sastra Indonesia, Fakultas Bahasa dan Seni, Universitas Negeri Manado.

\section{METODE}

Penelitian ini menggunakan metode kuantitatif, dengan jenis rancangan korelasional. Populasi penelitian ini mahasiswa Jurusan Pendidikan Bahasa dan Seni, Fakultas Bahasa dan Seni, Universitas Negeri Manado semester III, V, dan VII, yang berjumlah 420 orang. Kemudian sampel 
penelitian berjumlah 41 yang diambil dengan teknik stratification random sampling, yakni semester III 15 orang, semester V 14 orang, dan semester VII 12 orang.

Data mengenai motivasi belajar dan bimbingan akademik diperoleh dengan angket. Angket yang diberikan kepada responden menggunakan alat ukur yang disusun menurut model skala linkert (lima kemungkinan pilihan yang disusun berdasarkan kisi-kisi variabel bebas (X1, X2). Sedangkan data mengenai prestasi mahasiswa, menggunakan data IPK (indeks prestasi kumulatif) responden pada semester genap saat mereka berada di semester II, IV, dan VI.

Analisis data dilakukan setelah semua data yang dibutuhkan terkait dengan variabel penelitian terkumpul. Tahap analisis data dilakukan mengikuti langkah-langkah (1) penyajian data, di mana data yang telah terkumpul ditabulasikan berdasarkan variabelnya. Data yang ditabulasikan adalah data motivasi belajar (x1), data bimbingan belajar (x2), dan data prestasi akademik (Y) sesuai indeks prestasi kumulatif (IPK) mahasiswa pada semester genap. (2) Pengujian normalitas data, di mana data yang telah ditabulasikan berdasarkan jenis variabelnya terlebih dahulu dilakukan pengujian normalitas. Pengujian normalitas data dalam penelitian ini menggunakan rumus Chi Kuadrat. (3) Analisis data dan pengujian hipotesis, di mana data yang terkumpul dianalisis secara statistik dan pengujian hipotesis menggunakan statistik parametrik. Pengujian dilakukan untuk mengetahui korelasi antar variabel baik yang sifatnya sederhana maupun ganda. Pengujian untuk mengetahui korelasi sederhana digunakan rumus korelasi product moment.

\section{HASIL DAN PEMBAHASAN}

\section{Pengujian Normalitas Data}

Untuk menguji normalitas data ketiga variabel, yakni variabel motivasi belajar (X1), variabel bimbingan akademik (X2), dan variabel prestasi akademik (y) digunakan tabel penolong. Cara menghitung normalitas data digunakan rumus Chi Kuadrat dengan memanfaat tabel penolong berikut.

Tabel 1. Tabel Pengujian Normalitas Data Motivasi Belajar

\begin{tabular}{|c|c|c|c|c|c|}
\hline Interval & $\mathrm{f}_{\mathrm{o}}$ & fh & $\left(f_{o}-f_{h}\right)$ & $\left(f_{o}-f_{h}\right)^{2}$ & $\underset{\mathrm{f}_{\mathrm{h}}}{\left(\mathrm{f}_{\mathrm{o}}-\mathrm{f}_{\mathrm{h}}\right)^{2}}$ \\
\hline $57-61$ & 8 & 7,9 & 0,1 & 0,01 & 0,0 \\
\hline $62-66$ & 4 & 3,9 & 0,1 & 0,01 & 0,0 \\
\hline $67-71$ & 8 & 7,9 & 0,1 & 0,01 & 0,01 \\
\hline $72-76$ & 10 & 9.97 & 0,03 & 0,09 & 0,09 \\
\hline $77-81$ & 8 & 7,9 & 0,1 & 0,1 & 0,0 \\
\hline \multirow[t]{2}{*}{$82-86$} & 3 & 2,99 & 0,01 & 0,1 & 0,0 \\
\hline & 41 & 41,0 & 0.53 & 0,32 & 0,10 \\
\hline
\end{tabular}

Harga $F_{h}=19,51 \%$ x $41=7,9,9,75 \%$ x $41=3,9,19,51 \%$ x $41=7,9$,

$24,32 \% \times 41=9,97,19,51 \% \times \quad 41=7,9,7,31 \% 41=2,99$

Berdasarkan perhitungan tabel Chi Kuadrat di atas diperoleh Chi Kuadrat hitung $=30,6$. Harga Chi Kuadarat hitung ini selanjutnya dibandingkan dengan Chi Kuadrat tabel, dengan derajat kebebasan (dk) 6-5=5. Bila dk 5 dan taraf kesalahan 5\% maka harga Chi Kuadrat Tabel=11,070. Dengan demikian, karena Chi Kuadrat hitung 0,10 lebih kecil dari Chi Kuadrat tabel 11,070 maka distribusi data variabel motivasi belajar berdistribusi normal, sehingga memungkinkan untuk pengujian hipotesis.

Tabel 2. Tabel Pengujian Normalitas Data Bimbingan Akademik

\begin{tabular}{|c|r|r|r|r|r|}
\hline Interval & $\mathrm{F}_{\mathrm{o}}$ & $\mathrm{fh}$ & $\left(\mathrm{f}_{\mathrm{o}}-\mathrm{f}_{\mathrm{h}}\right)$ & $\left(\mathrm{f}_{\mathrm{o}}-\mathrm{f}_{\mathrm{h}}\right)^{2}$ & $\left(\left(\mathrm{f}_{\mathrm{o}}-\mathrm{f}_{\mathrm{h}}\right)_{\mathrm{h}} \mathrm{f}\right.$ \\
\hline $49-53$ & 12 & 11,99 & 0,01 & 0,01 & 0,00 \\
\hline $54-58$ & 21 & 20,99 & 0,01 & 0,01 & 0,00 \\
\hline
\end{tabular}




\begin{tabular}{|c|c|c|c|c|c|}
\hline $59-63$ & 4 & 7.79 & $-3,79$ & 14,36 & 1,84 \\
\hline $64-68$ & 3 & 2,99 & 0,01 & 0,01 & 0,03 \\
\hline $69-73$ & 1 & 0,99 & 0,01 & 0,01 & 0,01 \\
\hline & & & & 14,4 & 1,88 \\
\hline
\end{tabular}

Harga $F_{h}=29,26 \%$ x $41=11,9951,21 \%$ x $41=20,9919.0 \%$ x 41=7,79,

$7,31 \% \times 41=2,99,2,43 \% \times 41=0,99$

Berdasarkan perhitungan tabel Chi Kuadrat tersebut diperoleh Chi Kuadrat hitung $=1,88$. Harga Chi Kuadarat hitung ini selanjutnya dibandingkan dengan Chi Kuadrat tabel, dengan derajat kebebasan (dk) 5-4=1. Bila dk dan taraf kesalahan 1\% maka harga Chi Kuadrat Tabel= 15,086. Dengan demikian, karena Chi Kuadrat hitung 1,88 lebih kecil dari Chi Kuadrat tabel 15,086 maka distribusi data variabel bimbingan akademik berdistribusi normal, sehingga memungkinkan untuk pengujian hipotesis.

\section{Hubungan antara motivasi belajar $\left(\mathrm{x}_{1}\right)$ dengan prestasi akademik $(\mathrm{y})$}

Dari pengolahan dapat diketahui bahwa korelasi yang positif antara motivasi belajar dan prestasi akademik menunjukkan angka 2,063. Bila menggunakan $r$ tabel untuk $n=41$ dan kesalahan 5\% maka r tabel sebesar 0,308 , sedangkan $r$ hitung adalah 2,063. Ketentuan apabila $r$ hitung lebih kecil dari $r$ tabel maka Ho diterima dan Ha ditolak. Namun sebaliknya, bila r hitung lebih besar dari $r$ tabel maka Ha diterima. Dari hasil pengujian tampak bahwa $r$ hitung lebih besar dari $r$ tabel ataur hitung, 2,063 < $r$ tabel 0,308Dengan demikian korelasi 2,063 itu diterima atau dengan kata lain korelasinya signifikan.

\section{Hubungan antara Bimbingan Akademik dengan Prestasi Akademik}

Dari hasil pengolahan dapat diketahui bahwa korelasi yang positif antara motivasi belajar dengan prestasi akademik menunjukkan angka 2,27. Selanjutnya, untuk mengetahui signifikasi hubungan antara bimbingan akademik dengan prestasi akademik maka $r$ hitung dihubungkan dengan $r$ tabel. Bila menggunakan $r$ tabel untuk $\mathrm{n}=41$ dan taraf kesalahan sebesar 5\%, maka $r$ tabel sebesar 0,308, sedangkan $r$ hitung adalah 2,27. Ketentuannya bahwa apabila $r$ hitung lebih kecil dari $r$ tabel maka Ho diterima dan Ha ditolak. Namun sebaliknya, bila $r$ hitung lebih besar dari $\mathrm{r}$ tabel maka Ha diterima. Dari hasil pengujian tampak bahwa $\mathrm{r}$ hitung lebih besar dari $\mathrm{r}$ tabel, yakni: hitung, 2,27 < r tabel 0,308. Dengan demikian korelasi 2,063 itu diterima atau dengan kata lain korelasinya signifikan.

Berdasarkan hasil analisi data secara statistik dan pengujian hipotesis diperoleh hasil di mana hipotesis nol ditolak dan hipotesis alternatif diterima. Dapat dimaknai bahwa melalui pengujian yang dilakukan menunjukkan pada pasangan hipotesis yang pertama Ho ditolak dan Ha diterima. Dengan demikian, dapat dinyatakan bahwa "terdapat hubungan yang positif antara motivasi belajar dengan prestasi akademik", karena angka korelasi yang didapat $r$ hitung sebesar 2,063 lebih besar dari r tabel, yakni 0,308 .

Pada pasangan hipotesis yang kedua diperoleh juga hasil yang sama bahwa Ho ditolak dan Ha diterima. Dengan demikian, dapat dinyatakan bahwa "terdapat hubungan yang positif antara bimbingan akademik dengan prestasi akademik" diterima, karena angka korelasi yang diperoleh, r hitung 2,27 lebih besar dengan $r$ tabel, yakni 0,308.

Dari penafsiran tersebut maka dengan demikian hipotesis dalam penelitian ini diterima. Hipotesis yang dikemukan dalam penelitian ini adalah (1) terdapat hubungan positif antara antara motivasi belajar dengan prestasi akademik mahasiswa Jurusan Pendidikan Bahasa dan Sastra Indonesia, Fakultas Bahasa dan Seni, Universitas Negeri Manado dan (2) terdapat hubungan positif antara bimbingan akademik dengan prestasi belajar mahasiswa Jurusan Pendidikan Bahasa dan Sastra Indonesia, Fakultas Bahasa dan Seni, Universitas Negeri Manado.

Kedua hipotesis yang dikemukakan dapat dibuktikan atau dapat diterima. Kuatnya hubungan antar variabel motivasi belajar $\left(\mathrm{x}_{1}\right)$ dengan prestasi akademik $(\mathrm{y})$ dan bimbingan akademik $\left(\mathrm{x}_{2}\right)$ dengan prestasi akademik mengindikasikan perlunya dosen menumbuhkan motivasi belajar mahasiswa dan mengoptimalkan kegiatan bimbingan akademik. 


\section{KESIMPULAN}

Berdasarkan hasil penelitian yang telah dilakukan, maka disimpulkan, yakni terdapat hubungan yang positif antara motivasi belajar dengan prestasi akademik mahasiswa Jurusan Pendidikan Bahasa dan Sastra Indonesa, Fakultas Bahasa dan Seni, Universitas Negeri Manado. Pengolahan data secara statistik dengan rumus korelasi Pearson Product Moment menunjukkan bahwa angka korelasi yang diperoleh dari kedua variabel ini sebesar 2,063. Dari hasil pengujian tampak bahwa $\mathrm{r}$ hitung 2,063 lebih besar dari $r$ tabel 0,308. Dengan demikian korelasinya signifikan. Terdapat hubungan yang positif antara bimbingan akademik dengan prestasi akademik mahasiswa Jurusan Pendidikan Bahasa dan Sastra Indonesia, Fakultas Bahasa dan Seni, Universitas Negeri Mamando. Pengolahan data secara statistik dengan rumus korelasi Pearson Product Moment menunjukkan hubungan yang positif antara motivasi belajar dengan prestasi akademik menunjukkan angka 2,27. Jika dihubungkan dengan $r$ tabel sebesar 0,308, sedangkan $r$ hitung adalah 2,27. Dari hasil ini tampak bahwa $r$ hitung lebih besar dari $r$ hitung sehingga, hubungannya sangat signifikan. 


\section{DAFTAR PUSTAKA}

Djamarah, SB. 2002. Psikologi Belajar. Cetakan I. Jakarta : PT Rineke Cipta..

Kartadinata, S, Kemandirian Belajar dan Orientasi Nilai Mahasiswa. Bandung: PPS, 2001. Majid M. 2013. Strategi Pembelajaran: Jakarta: Grafindo.

Sugiyono. 2008. Metode Penelitian Pendidikan. Pendekatan Kuantitatif, Kualitatif, dan R\&D. Bandung: Alfabeta.

Tu’u, T. 2004. Peran Disiplin pada Perilaku dan Prestasi Siswa. Jakarta : PT Grasindo. 